\title{
Low health-related quality of life is a predictor of major adverse cardiovascular events in patients with chronic nonischemic heart failure
}

\author{
Bożena Szyguła-Jurkiewicz ${ }^{1}$, Michał Zakliczyński², Aleksander Owczarek³ ${ }^{3}$ Robert Partyka ${ }^{4}$, \\ Mateusz Mościński ${ }^{5}$, Robert Pudlo ${ }^{6}$, Marcin Kaczmarczyk ${ }^{2}$, Marian Zembala², Lech Poloński ${ }^{1}$ \\ ${ }_{1}^{1}{ }^{\text {rd }}$ Department of Cardiology, Medical University of Silesia, Katowice, Silesian Center for Heart Diseases, Zabrze, Poland \\ ${ }^{2}$ Department of Cardiac Surgery and Transplantation, Medical University of Silesia, Katowice, Silesian Center for Heart \\ Diseases, Zabrze, Poland \\ ${ }^{3}$ Division of Statistics, School of Pharmacy and the Division of Laboratory Medicine, Medical University of Silesia, Katowice, Poland \\ ${ }^{4}$ Department of Anesthesiology, Intensive Care and Emergency Medicine, Medical University of Silesia, Katowice, Poland \\ ${ }^{5}$ Silesian Center for Heart Diseases, Zabrze, Poland \\ ${ }^{6}$ Department of Psychiatry, Medical University of Silesia, Katowice, Poland
}

Kardiochirurgia i Torakochirurgia Polska 2014; 11 (3): 283-288

\begin{abstract}
Introduction: The need to indentify patients with chronic heart failure (CHF) at a higher risk of major adverse cardiovascular events (MACEs) has become increasingly important; therefore, new parameters, such as health-related quality of life (HRQoL), are gaining ground.

The aim of this study was to determine the risk factors for MACEs, with a special emphasis on HRQoL in chronic non-ischemic heart failure (NIHF) patients.

Material and methods: This prospective study enrolled 271 hospitalized patients with heart failure symptoms (NYHA II and III), without neoplastic disease, diabetes, hepatic cirrhosis or chronic kidney disease, who had been receiving optimal medical treatment. In all the patients, laboratory examinations, electrocardiography, echocardiography, a 6-minute walking test, invasive right heart pressure measurements and coronary angiography were performed. HRQoL assessment was conducted with the Short-Form Health Survey (SF-36). Clinical observation commenced on admission to the hospital and lasted 3 years. Data concerning MACE incidence (death, transplantation, circulatory support, hospitalization) were obtained during outpatient visits. Results: The final analysis enrolled 202 patients, while 17 patients were lost to follow up. The MACE incidence was $42.1 \%$. Major adverse cardiovascular events risk factors in multiple factor analysis were: alkaline phosphatase (hazard ratio [HR] = 1.01; $p<0.05)$; right ventricular end-diastolic diameter $(H R=$ 1.08; $p<0.001)$; hsCRP $(\mathrm{HR}=1.04 ; p<0.05)$; and the following HRQoL indices: Bodily Pain $(\mathrm{HR}=0.98 ; p<0.05)$ and Mental Health $(\mathrm{HR}=0.97 ; p<0.01)$.

Conclusions: Low values for HRQoL parameters (Bodily Pain and Mental Health), right ventricular end-diastolic diameter, serum concentration of hsCRP and alkaline phosphatase are prognostic factors in NIHF patients.
\end{abstract}

Key words: quality of life, heart failure, prognosis.

\section{Streszczenie}

Wstęp: Ze względu na to, że spośród chorych z przewlekłą niewydolnością serca (chronic heart failure - CHF) konieczne jest wyselekcjonowanie grupy zagrożonej wysokim ryzykiem występowania poważnych niekorzystnych zdarzeń sercowych (major adverse cardiovascular events - MACEs), wzrasta znaczenie nowych parametrów prognostycznych, takich jak jakość życia zależna od stanu zdrowia (health-related quality of life - HRQoL). Celem pracy było określenie czynników ryzyka niekorzystnych zdarzeń sercowych, ze szczególnym uwzględnieniem HRQoL w grupie chorych z niewydolnością serca o etiologii nie-niedokrwiennej (non-ischemic heart failure - NIHF).

Materiat i metody: Do prospektywnego badania włączono 271 hospitalizowanych chorych z objawami CHF (NYHA II i III), bez choroby nowotworowej, cukrzycy, marskości wątroby lub przewlekłej choroby nerek, którzy otrzymywali optymalne leczenie farmakologiczne. U wszystkich tych chorych przeprowadzono badanie laboratoryjne, elektrokardiograficzne, echokardiograficzne, test 6-minutowego marszu, inwazyjne pomiary ciśnień w prawym sercu oraz koronarografię. Do oceny HRQoL stosowano kwestionariusz SF-36. Obserwacja kliniczna została rozpoczęta przy przyjęciu do szpitala i trwała 3 lata. Dane dotyczące występowania MACEs (zgon, transplantacja, wspomaganie krążenia, hospitalizacja) uzyskiwano na podstawie wizyt kontrolnych.

Wyniki: Ostatecznie analizie poddano 202 chorych; danych dotyczących obserwacji odległej nie uzyskano u 17 chorych. Częstość występowania MACEs wynosiła 42,1\%. Czynnikami ryzyka zgonu w analizie wieloczynnikowej były: stężenie fosfatazy alkalicznej ( $H R=1,01 ; p<0,05)$; wymiar końcoworozkurCzowy prawej komory $(\mathrm{HR}=1,08 ; p<0,001)$; stężenie hsCRP ( $\mathrm{HR}=1,04 ; p<0,05)$ oraz następujące wskaźniki HRQoL: ból somatyczny $(H R=0,98 ; p<0,05)$ i zdrowie psychiczne $(H R=$ $=0,97 ; p<0,01)$. 
Wnioski: Niskie wartości parametrów HRQoL (ból somatyczny i zdrowie psychiczne), wymiar końcoworozkurczowy prawej komory, stężenie hsCRP w surowicy oraz stężenie fosfatazy alkalicznej są czynnikami rokowniczymi u chorych z niewydolnością serca o etiologii nie-niedokrwiennej.

Słowa kluczowe: jakość życia, niewydolność serca, rokowanie.

\section{Introduction}

The need to indentify patients with chronic heart failure (HF) at a higher risk of mortality has become increasingly important. Risk stratification facilitates the selection of patients who will benefit the most from detailed clinical observation, intensive educational programs, aggressive pharmacological treatment and alternative methods, such as automatic implantable cardioverter-defibrillators (ICDs), cardiac resynchronization therapy (CRT) and eventually heart transplantation $[1,2]$. Although prognostic factors in $\mathrm{HF}$ patients have been scrutinized for many years, their type and prognostic value can vary depending on the population studied, the New York Heart Association (NYHA) class and, in particular, the treatment used [1-4]. Prognostic factors have been affected by continuing progress in medicine and by changing standards in HF management [1-4]. In addition to the commonly implemented clinical parameters for risk stratification in this group of patients, subjective indices, such as health-related quality of life (HRQoL), have gained ground [5-9]. Over the last decade, the SF-36 Health Survey has been the most frequently used tool for HRQoL evaluation in individuals with cardiovascular diseases [10-13].

The aim of the study was to determine the risk factors for major adverse cardiovascular events (MACEs) in patients with chronic nonischemic heart failure (NIHF).

\section{Material and methods}

This prospective study encompassed consecutive patients with chronic NIHF, NYHA classes II and III, who had been admitted to the hospital for invasive diagnostics and further management.

The entry criteria included HF symptoms confirmed at least 6 months before index hospitalization and an enlarged left ventricle (left ventricular end diastolic diameter - LVEDD > $57 \mathrm{~mm}$ ) with an impaired left ventricular ejection fraction $(\mathrm{LVEF})<35 \%$.

Patients were excluded if they had had coronary artery disease confirmed on coronary angiography, respiratory diseases associated with pulmonary hypertension, neoplastic disease, documented infectious diseases at least 3 months before inclusion, diabetes, or advanced liver or kidney disease (estimated glomerular filtration rate-eGFR $<30 \mathrm{ml} / \mathrm{min} / 1.73 \mathrm{~m}^{2}$ ) or if they were listed as heart transplant candidates before the index hospitalization.

The clinical follow-up lasted 3 years. During hospitalization, each patient's history was obtained, followed by physical and laboratory examinations. Echocardiography, resting electrocardiography, the 6-minute walk test, invasive right heart pressure measurements and coronary angiography were performed. On admission, HRQoL was assessed using the Short-Form Health Survey: SF-36 (Qualitymetric ${ }^{\circledR}$ ). The questionnaire consists of 36 questions grouped into eight parameters: Physical Functioning (PF); Role Physical (RP); Bodily Pain (BP); General Health (GH); Vitality (V); Social Functioning (SF); Role Emotional (RE); and Mental Health $(\mathrm{MH})$. Data concerning later follow-ups were obtained at consecutive elective visits, and surveys were completed by the patients via telephone contact with the patients or their relatives. Major adverse cardiovascular events were defined as all-cause death, urgent heart transplantation, left ventricular support implantation or any other re-hospitalization due to HF exacerbation. The local Bioethics Committee approved the study protocol.

\section{Statistical analysis}

Data with a normal distribution are presented as the means \pm SDs with $95 \%$ confidence intervals (Cls). Data with a non-normal distribution and ordinal data are presented as medians with interquartile ranges. Qualitative data are presented as percentages. To compare data between the two groups, Student's t-test was used for data with normal or normalized distribution, the homogeneity of variances was assessed using Levene's test, and the Mann-Whitney $U$ test was used for the remaining data. The normality of distribution was assessed using the Shapiro-Wilk test. To compare dichotomous variables, the $\chi^{2}$ test or its appropriate modifications (Yates' correction) was used. The effect of the variables on the incidence of MACE was assessed using Cox's proportional hazards model. Variables that were statistically significant $(p<0.05)$ in the univariate analysis were included in the multiple factor analysis of Cox's proportional hazard with backward elimination. The results are presented as hazard ratios (HRs) with 95\% confidence intervals (Cls), Wald's statistics and significance levels. Receiver operator characteristic (ROC) curves were plotted to determine the cut-off points for parameters that were significant in the multiple factor analysis. The results are presented as AUC (area under curve), sensitivity, and specificity with 95\% Cls and significance levels. The diagrams of MACE risk assessment were developed based on classification trees. $p$-values $<0.05$ were considered statistically significant. All the calculations were performed using Statistica 7.1, version $\mathrm{PL}, \mathrm{MS}$ Office Excel and the R software environment.

\section{Results}

Between 2008 and 2010, 265 consecutive patients with symptomatic HF were qualified for invasive diagnostics at 
the Clinical Department of Cardiology, Medical University of Silesia. For at least 6 months prior to admission, all of them had been receiving optimal medical treatment: an angiotensin converting enzyme inhibitor or an angiotensin II receptor antagonist; a $\beta$-receptor antagonist (slow-release metoprolol or carvedilol preparations); spironolactone; and furosemide (Fig. 1).

After the baseline evaluation, 217 patients met the entry criteria and were enrolled into the study. The final 3-year clinical follow-up encompassed 202 patients from whom complete clinical data were obtained. The baseline patient characteristics are presented in Table I.

During the follow-up, death occurred in $17.8 \%$ of patients; transplantation was performed on $3 \%$ and left ventricular support on $3 \%$, and hospitalization due to $\mathrm{HF}$ exacerbation was necessary in $31.7 \%$ of patients. Eightynine $(44.1 \%)$ patients underwent ICD implantation, while 21 (10.4\%) underwent resynchronization therapy.

The incidence of MACE was observed in 85 cases (42.1\%). Accordingly, the studied patients were divided into two groups: A $(n=117)$ without MACE at follow-up; and $B(n=85)$ with MACE. The two groups differed significantly with regard to all of the HRQoL parameters (Table II). The greatest differences concerned the parameters for mental functioning. The risk factors for MACE obtained from Cox's proportional hazard model are presented in
Table III. The results of ROC analysis are presented in Table IV.

\section{Discussion}

This study analyzed the incidence of MACE and the factors affecting late outcomes in patients with NIHF. Unlike most of the available studies, in addition to clinical param-

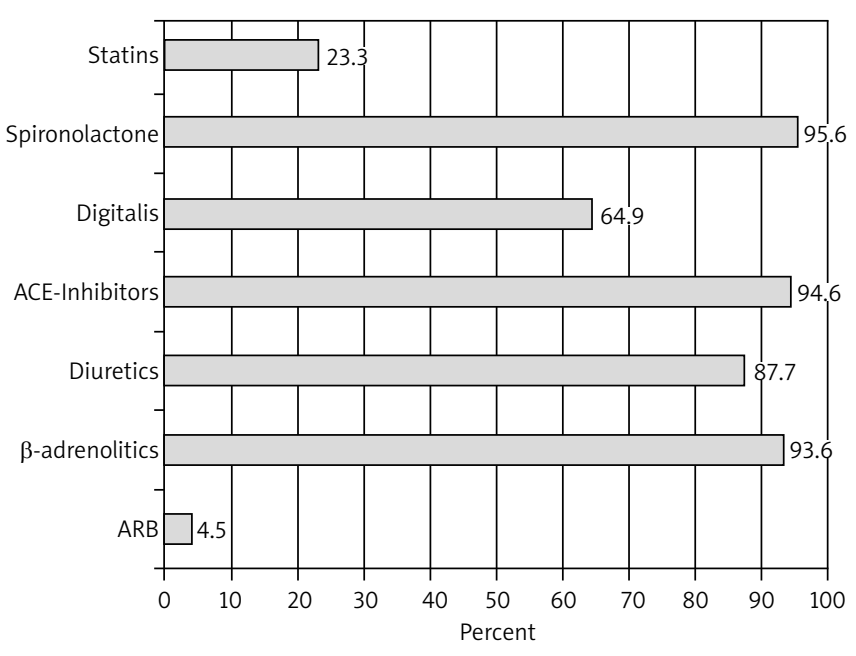

ARB - angiotensin II receptor blockers

Fig. 1. Heart failure treatment on admission and at discharge

Tab. I. Basic patient characteristics

\begin{tabular}{|c|c|c|c|}
\hline \multirow[t]{2}{*}{ Factors } & Group A (without MACEs) & Group B (with MACEs) & \multirow[t]{2}{*}{$p$} \\
\hline & $n=117$ & $n=85$ & \\
\hline Age [years] & $\begin{array}{c}50.0 \\
42.0 / 54.0\end{array}$ & $\begin{array}{c}47.0 \\
40.0 / 54.0\end{array}$ & NS \\
\hline Men [\%] & $100(85.5 \%)$ & $67(78.8 \%)$ & NS \\
\hline HF duration [months] & $\begin{array}{c}12.0 \\
6.0 / 36.0 \\
\end{array}$ & $\begin{array}{c}24.0 \\
7.0 / 60.0 \\
\end{array}$ & $<0.05$ \\
\hline NYHA II & 99 (84.6\%) & $65(76.5 \%)$ & NS \\
\hline 6-minute walk test [m] & $401.4 \pm 52.6$ & $330.5 \pm 69.9$ & $<0.001$ \\
\hline LVEF [\%] & $\begin{array}{c}30.0 \\
25.0 / 34.0 \\
\end{array}$ & $\begin{array}{c}20.0 \\
24.0 / 34.0 \\
\end{array}$ & NS \\
\hline LVEDV [mm] & $204.1 \pm 71.8$ & $222.9 \pm 81.2$ & 0.0656 \\
\hline $\operatorname{RVEDD}[\mathrm{mm}]$ & $26.0 \pm 6.0$ & $29.8 \pm 7.5$ & $<0.001$ \\
\hline$E / A$ & $\begin{array}{c}1.41 \\
0.46 / 1.71 \\
\end{array}$ & $\begin{array}{c}1.74 \\
1.21 / 3.61 \\
\end{array}$ & $<0.001$ \\
\hline $\mathrm{eGFR}<90\left[\mathrm{ml} / \mathrm{min} / 1.73 \mathrm{~m}^{2}\right]$ & 59 (51.7\%) & $51(60.7 \%)$ & NS \\
\hline $\mathrm{hsCRP}[\mathrm{mg} / \mathrm{l}]$ & $\begin{array}{c}1.70 \\
1.03 / 3.22 \\
\end{array}$ & $\begin{array}{c}2.73 \\
1.20 / 5.61 \\
\end{array}$ & $<0.05$ \\
\hline NT-proBNP [pg/ml] & $\begin{array}{c}620.1 \\
296.1 / 1218.1 \\
\end{array}$ & $\begin{array}{c}1701.0 \\
301.1 / 3757.0\end{array}$ & $<0.001$ \\
\hline Alkaline phosphatase [U/I] & $\begin{array}{c}62.0 \\
52.0 / 72.0 \\
\end{array}$ & $\begin{array}{c}74.0 \\
57.0 / 90.0 \\
\end{array}$ & $<0.01$ \\
\hline Bilirubin [mmol/l] & $18.5 \pm 9.3$ & $22.2 \pm 12.1$ & $<0.05$ \\
\hline
\end{tabular}

E/A - E/A ratio, eGFR - estimated glomerular filtration rate, HF - heart failure, hsCRP - high sensitivity C-reactive protein, LVEDV - left ventricular end diastolic volume, LVEF - left ventricular ejection fraction, MACEs - major adverse cardiovascular events, NT-proBNP - N-terminal pro-B-type natriuretic peptide, NYHA - New York Heart Association, RVEDD - right ventricular end diastolic diameter 
Low health-related quality of life is a predictor of major adverse cardiovascular events in patients...

Tab. II. Basic characteristics of patient HRQoL (health-related quality of life) - divided by groups

\begin{tabular}{lccc} 
HRQoL parameters & Group A & Group B & $p$ \\
\cline { 2 - 3 } Physical Functioning (PF) & $117(57.9 \%)$ & $85(42.1 \%)$ & $<0.05$ \\
\hline \multirow{2}{*}{ Role Physical (RP) } & 40.0 & 30.0 & $<.0 / 47.5$ \\
\hline \multirow{2}{*}{ Bodily pain (BP) } & $25.0 / 50.0$ & 25.0 & $<.01$ \\
\hline \multirow{2}{*}{ General Health (GH) } & 25.0 & $18.7 / 31.2$ & $<0.001$ \\
\hline \multirow{2}{*}{ Vitality (V) } & $25.0 / 50.0$ & 22.0 & $<0.001$ \\
\hline \multirow{2}{*}{ Social Functioning (SF) } & 51.0 & $22.0 / 46.5$ & $<.01$ \\
\hline \multirow{2}{*}{ Role Emotional (RE) } & 25.0 & 15.0 & $<0.001$ \\
\hline \multirow{2}{*}{ Mental Health (MH) } & $15.0 / 35.0$ & $5.0 / 27.5$ & $<0.001$ \\
\hline
\end{tabular}

Tab. III. Risk factors for major adverse cardiovascular events. Multivariable stepwise backward factor analysis

\begin{tabular}{lllll} 
Parameter & HR & $\pm 95 \% \mathrm{Cl}$ & Wald statistics & $p$ \\
RVEDD [mm] & 1.0830 & $1.0417-1.1259$ & 16.18 & $<0.001$ \\
\hline E/A & 1.1889 & $0.9846-1.4356$ & 3.23 & 0.0721 \\
\hline hsCRP [mg/dl] & 1.0468 & $1.0123-1.0825$ & 7.16 & $<0.01$ \\
\hline ALP [U/l] & 1.0112 & $1.0025-1.0199$ & 6.33 & $<0.05$ \\
\hline BP (SF-36) & 0.9798 & $0.9638-0.9960$ & 5.92 & $<0.05$ \\
\hline MH (SF-36) & 0.9742 & $0.9557-0.9930$ & 7.16 & $<0.01$ \\
\hline V (SF-36) & 1.0204 & $0.9968-1.0447$ & 2.86 & 0.0910 \\
\hline
\end{tabular}

ALP - alkaline phosphatase, BP - Bodily Pain, E/A - E/A ratio, hsCRP - high sensitivity C-reactive protein, MH - Mental Health, RVEDD - right ventricular end diastolic diameter, $\mathrm{V}$ - Vitality

Tab. IV. Results of ROC (receiver operator characteristic) analysis

\begin{tabular}{lcccccccc} 
& $P$ & AUC & $\pm 95 \% \mathrm{Cl}$ & Cut-off & Sensitivity & $\pm 95 \% \mathrm{Cl}$ & Specificity & $\pm 95 \% \mathrm{Cl}$ \\
ALP [U/I] & $<0.001$ & 0.644 & $0.568-0.714$ & $>64.2$ & 56.67 & $46.7-69.9$ & 57.43 & $47.2-67.2$ \\
\hline $\mathrm{hsCRP}[\mathrm{mg} / \mathrm{dl}]$ & $<0.05$ & 0.603 & $0.529-0.673$ & $>1.97$ & 62.20 & $50.8-72.7$ & 60.38 & $50.4-69.7$ \\
\hline E/A & $<0.001$ & 0.653 & $0.574-0.727$ & $>1.4$ & 62.12 & $49.3-73.8$ & 55.91 & $45.2-66.2$ \\
\hline RVEDD [mm] & $<0.001$ & 0.651 & $0.580-0.718$ & $>28$ & 56.10 & $44.7-67.0$ & 64.04 & $54.5-72.8$ \\
\hline Bodily Pain & $<0.001$ & 0.707 & $0.637-0.770$ & $\leq 32$ & 66.67 & $55.5-76.6$ & 60.55 & $50.7-69.8$ \\
\hline Mental Health & $<0.001$ & 0.705 & $0.635-0.768$ & $\leq 40$ & 65.48 & $54.3-75.5$ & 63.30 & $53.5-72.3$ \\
\hline Vitality & $<0.001$ & 0.646 & $0.574-0.714$ & $\leq 31$ & 64.29 & $53.1-74.4$ & 62.39 & $52.6-71.5$ \\
\hline
\end{tabular}

ALP - alkaline phosphatase, BP - Bodily Pain, E/A - E/A ratio, hsCRP - high sensitivity C-reactive protein, MH - Mental Health, RVEDD - right ventricular end diastolic diameter, $\mathrm{V}$ - Vitality

eters, we also assessed HRQoL parameters. To the best of our knowledge, this is the first study that determined the HRQoL parameter's values below which there was an increase in MACE risk. Two HRQoL parameters - Bodily Pain and Mental Health - were independent prognostic factors of poor survival in our analysis.
Only a few analyses have scrutinized the prognostic value of HRQoL parameters in patients with chronic HF [8-13], although some have emphasized the patients' functional status according to NYHA class as a potent prognostic factor in HF [19]. However, the source of subjectivity in this situation is the physician who establishes the functional 
class on the basis of clinical information [15]. In a population of patients enrolled in the COMET trial, Ekman et al. examined the effects of HF symptoms on the incidence of death and disease exacerbation requiring hospitalization [16]. Interestingly, it was the patient using a pre-defined scale, instead of the physician, who made the assessment. The authors concluded that the presence and severity of complaints reported by the patient should be the most important factors for planned therapy, as they had prognostic value for death and hospitalization. However, NYHA class and symptom severity only refer to the physical aspects of HRQoL and disregard mental functioning, which, in our study, proved to be an important predictive factor. Our results were similar to those of Rodriguez-Artalejo, who observed the significant prognostic value the HRQoL indices of the SF-36 questionnaire [8]. The frequency of hospitalizations during a 6-month follow-up was greater in patients with lower scores on Mental Health $(H R=1.65)$, Physical Functioning $(H R=1.65)$ and General Health $(H R=1.73)$. The analysis by Faller in a group of more than 200 patients with chronic HF confirmed the prognostic value of Mental Health [17]. The Mental Component Summary (MCS) of the SF-36 questionnaire and the Mental Health Component of the Kansas City Cardiomyopathy Questionnaire (KCCQ) were found to be the independent prognostic factors of poor 3-year results in this population. Slightly different results were obtained by Alla et al., who analyzed the HRQoL of patients in the EPICAL trial using the generic Duke Health Profile (DPH) and the specific Minnesota questionnaire. The risk factors for hospitalization over a one-year followup in that study were Physical, Mental and Social Functioning, as well as General Health [18]. The prognostic value of specific questionnaire results was not very different from that of the generic results in this study.

Another prognostic factor in our population was hsCRP. Like many other authors, we have observed that inflammatory processes play a role in HF etiopathogenesis [19]. Lamblin et al. noticed a slight prognostic value of hsCRP in a population of patients with stable HF [19]. The analyzed group was similar to our population with regard to the percentage of patients in NYHA classes II and III, LVEF, follow-up duration and treatment method. The groups differed with regard to HF etiology.

In a population analyzed by Alonso-Martínez et al., an elevated concentration of hsCRP was associated with an increased risk of death and re-hospitalization over an 18-month follow-up [20]. The authors analyzed all HF cases, regardless of etiology. By analyzing more than 100 patients with chronic HF in NYHA classes II, III and IV, Yin et al. demonstrated that the mean hsCRP concentrations did not differ significantly between groups with ischemic or non-ischemic etiology [21]. At a cut-off point of $2.97 \mathrm{mg} / \mathrm{l}$, hsCRP was an independent risk factor for MACE at one-year follow-up [21]. Based on an analysis of more than 5,000 patients, Anand concluded that elevated hsCRP increased the risk of death or hospitalization regardless of HF etiology [22].
Enlarged RVEDD, which was assessed using two-dimensional echocardiography, was also shown to increase the risk of MACE in our group of patients. These results are similar to those of Spinarova et al., who, based on an analysis of patients with symptomatic HF associated with coronary disease and DCM, demonstrated that the more impaired the right ventricular systolic function was, the larger its size and the values of invasively measured right heart pressure were [23]. The right ventricular ejection fraction was confirmed by de Groote et al. and Di Salvo et al. to be of independent prognostic value for MACE in patients with chronic systolic HF [24, 25].

The last factor that increased the risk of MACE in our group of patients was the concentration of alkaline phosphatase. There has been a paucity of reports concerning the prognostic value of cholestasis in HF patients [26-28]. Ess et al. followed up more than 1,000 outpatients with stable HF - ischemic (30\%) and non-ischemic (70\%) - for 39 months (median) [26]. The independent risk factor for death or transplantation was the concentration of GGTP $(\mathrm{HR}=$ 2.12), with a cut-off point of $36.5 \mathrm{U} / \mathrm{l}$ in women and $70.5 \mathrm{U} / \mathrm{l}$ in men [26]. In the study of more than 2,500 HF patients by Allen et al. [27], the concentration of bilirubin was the strongest independent prognostic factor over a 38-month follow-up (median). Bilirubin was also an independent risk factor for death or hospitalization in an analysis by Shinagawa et al. [28] of almost 200 patients with systolic HF, who were followed up for 30 months. Based on a retrospective analysis of more than 100 individuals, Lau et al. concluded that cholestasis indices were correlated strongly with the severity of tricuspid insufficiency [29]. The study by Poelzl et al. of more than 1,000 HF patients, who were followed up for 36 months, showed that two cholestasis indices - alkaline phosphatase and $\gamma$-glutamyltranspeptidase - were independent risk factors for death (depending on the model) [30].

The main limitation of the present study was that the patients originated from one center. In addition, the strengths of this study are its prospective character, the relatively large group of patients with homogenous HF etiologies, and the study's long follow-up.

\section{Conclusions}

In the group of NIHF patients, late outcomes were affected by low values for health-related quality of life parameters (Bodily Pain and Mental Health), right ventricular end-diastolic diameter, serum concentration of hsCRP and alkaline phosphatase.

\section{Disclosure}

The authors report no conflict of interest.

\section{References}

1. McMurray JJ, Adamopoulos S, Anker SD, Auricchio A, Böhm M, Dickstein K, Falk V, Filippatos G, Fonseca C, Gomez-Sanchez MA, Jaarsma T, Køber L, Lip GY, Maggioni AP, Parkhomenko A, Pieske BM, Popescu BA, Rønnevik PK, 
Rutten FH, Schwitter J, Seferovic P, Stepinska J, Trindade PT, Voors AA, Zannad F, Zeiher A; ESC Committee for Practice Guidelines. ESC Guidelines for the diagnosis and treatment of acute and chronic heart failure 2012: The Task Force for the Diagnosis and Treatment of Acute and Chronic Heart Failure 2012 of the European Society of Cardiology. Developed in collaboration with the Heart Failure Association (HFA) of the ESC. Eur Heart J 2012; 33: 1787-1847.

2. The Task Force on Heart Failure of the European Society of Cardiology (ESC). Kardiol Pol 2008; 66: 11 (suppl. 4).

3. Szyguła-Jurkiewicz B, Owczarek A, Duszańska A, Sikora J, Lekston A, Pudlo R, Wojnicz R, Poloński L. Long-term prognosis and risk factor for cardiac adverse events in patients with chronic systolic heart failure due to hypertension. Pol Arch Med Wewn 2008; 5: 280-288.

4. Zugck C, Haunstetter A, Krüger C, Kell R, Schellberg D, Kübler W, Haass M. Impact of beta-blocker treatment on the prognostic value of currently used risk predictors in congestive heart failure. J Am Coll Cardiol 2002; 39: 16151622.

5. Senni M, Santilli G, Parrella P, De Maria R, Alari G, Berzuini C, Scuri M, Filippi A, Migliori M, Minetti B, Ferrazzi P, Gavazzi A. A novel prognostic index to determine the impact of cardiac conditions and co-morbidities on one-year outcome in patients with heart failure. Am J Cardiol 2006; 98: 1076-1082.

6. Cohn JN, Johnson GR, Shabetai R, Loeb H, Tristani F, Rector T, Smith R, Fletcher R. Ejection fraction, peak exercise oxygen consumption, cardiothoracic ratio, ventricular arrhythmias and plasma norepinephrine as determinants of prognosis in heart failure. The V-Heft VA Cooperative Studies Group. Circulation 1993; 87 (suppl): V15-V16.

7. de Groote P, Dagorn J, Soudan B, Lamblin N, McFadden E, Bauters C. B-type natriuretic peptide and peak exercise oxygen consumption provide independent information for risk stratification in patients with stable congestive heart failure. J Am Coll Cardiol 2004; 43: 1584-1589.

8. Rodriquez-Artalejo F, Guallar-Castillon P, Pascual CR, Otero CM, Montes AO, Garcia AN, Conthe P, Chiva MO, Banegas JR, Herrera MC. Health-related quality of life as a predictor of hospital readmission and death among patients with heart failure. Arch Intern Med 2005; 165: 1274-1279.

9. Faller H, Stork S, Schowalter M, Steinbuchel M, Wollner V, ErtI G, Angermann CE. Is health-related quality of life an independent predictor of survival in patients with chronic heart failure? J Psychosom Res 2007; 63: 533-538.

10. Szyguła-Jurkiewicz B, Owczarek A, Wojnicz R, Pudlo R, Schmidt B, Fryś-Kubala M, Klimaszewska K, Zembala M, Poloński L. Wpływ optymalnego leczenia farmakologicznego na jakość życia u chorych z przewlekłą skurczową niewydolnością serca w okresie 3 lat obserwacji. Kardiochir Torakochir Pol 2010; 7: 331-337.

11. Graf J, Koch M, Dujardin R, Kersten A, Janssens U. Health-related quality of life before, 1 month after and 9 months after intensive care in medical cardiovascular and pulmonary patients. Crit Care Med 2003; 31: 2163-2169.

12. Phillips Bute B, Mathew J, Blumenthal JA, Welsh-Bohmer K, White WD, Mark D, Landolfo K, Newman MF. Female gender is associated with impaired quality of life 1 year after coronary artery bypass surgery. Psychosom Med 2003; 65: 944-951.

13. Szyguła-Jurkiewicz B, Zembala M, Wilczek K, Wojnicz R, Poloński L. Healthrelated quality of life after percutaneous coronary intervention versus coronary artery bypass graft surgery in patients with acute coronary syndromes without ST-segment elevation. 12-month follow up. Eur J Cardiothorac Surg 2005; 27: 882-886.

14. Bennett JA, Riegel B, Bittner V, Nichols J. Validity and reliability of the NYHA classes for measuring research outcomes in patients with cardiac disease. J Heart Lung Transplant 2002; 31: 262-270.
15. Tiesinga LJ, Dijkstra A, Dassen TW, Halfens RJ, van den Heuvel WJ. Are nurses able to assess fatigue, exertion fatigue and types of fatigue in residential home patients? Scand J Caring Sci 2002; 16: 129-136.

16. Ekman I, Cleland JG, Swedberg K, Charlesworth A, Metra M, Poole-Wilson PA. Symptoms in patients with heart failure are prognostic predictors: insights from COMET. J Card Fail 2005; 11: 288-292.

17. Faller H, Stork S, Schowalter M, Steinbuchel M, Wollner V, Ertl G, Angermann CE. Is health-related quality of life an independent predictor of survival in patients with chronic heart failure? J Psychosom Res 2007; 63: 533-538.

18. Alla F, Briancon S, Guillemin F, Juilliere Y, Mertes PM, Villemot JP, Zannad F. for the EPICAL Investigators. Self-rating of quality of life provides additional prognostic information in heart failure. Insights into the EPICAL study. Eur J Heart Fail 2002; 4: 337-343.

19. Lamblin N, Mouquet F, Hennache B, Dagorn J, Susen S, Bauters C, de Groote P. High-sensitivity C-reactive protein: potential adjunct for risk stratification in patients with stable congestive heart failure. Eur Heart J 2005; 26: $2245-$ 2250.

20. Alonso-Martínez JL, Llorente-Diez B, Echegaray-Agara M, Olaz-Preciado F, Urbieta-Echezarreta M, González-Arencibia C. C-reactive protein as a predictor of improvement and readmission in heart failure. Eur J Heart Fail 2002; 4: 331-336.

21. Yin WH, Chen JW, Jen HL, Chiang MC, Huang WP, Feng AN, Young MS, Lin SJ. Independent prognostic value of elevated high-sensitivity C-reactive protein in chronic heart failure. Am Heart J 2004; 147: 931-938.

22. Anand IS, Latini R, Florea VG, Kuskowski MA, Rector T, Masson S, Signorini S, Mocarelli P, Hester A, Glazer R, Cohn JN; Val-HeFT Investigators. C-reactive protein in heart failure. Prognostic value and the effect of valsartan. Circulation 2005; 112: 1428-1434.

23. Spinarová L, Meluzín J, Toman J, Hude P, Krejcí J, Vítovec J. Right ventricular dysfunction in chronic heart failure patients. Eur J Heart Fail 2005; 7: 485-489.

24. de Groote P, Millaire A, Foucher-Hossein C, Nugue O, Marchandise X, Ducloux $G$, Lablanche JM. Right ventricular ejection fraction is an independent predictor of survival in patients with moderate heart failure. J Am Coll Cardiol 1998; 32: 948-954.

25. Di Salvo TG, Mathier M, Semigran MJ, Dec GW. Preserved right ventricular ejection fraction predicts exercise capacity and survival in advanced heart failure. J Am Coll Cardiol 1995; 25: 1143-1153.

26. Ess M, Mussner-Seeber C, Mariacher S, Lorsbach-Koehler A, Pachinger O, Frick M, Ulmer H, Poelzl G. $\gamma$-Glutamyltransferase rather than total bilirubin predicts outcome in chronic heart failure. J Card Fail 2011; 17: 577-584.

27. Allen LA, Felker GM, Pocock S, McMurray JJ, Pfeffer MA, Swedberg K, Wang D, Yusuf S, Michelson EL, Granger CB; CHARM Investigators. Liver function abnormalities and outcome in patients with chronic heart failure: data from the Candesartan in Heart Failure: Assessment of Reduction in Mortality and Morbidity (CHARM) program. Eur J Heart Fail 2009; 11: 170-177.

28. Shinagawa H, Inomata T, Koitabashi T, Nakano H, Takeuchi I, Naruke T, Ohsaka T, Nishii M, Takehana H, Izumi T. Prognostic significance of increased serum bilirubin levels coincident with cardiac decompensation in chronic heart failure. Circ J 2008; 72: 364-369.

29. Lau GT, Tan HC, Kritharides L. Type of dysfunction in heart failure and its relation to the severity of tricuspid regurgitation. Am J Cardiol 2002; 90: 1405-1409.

30. Poelzl G, Ess M, Mussner-Seeber C, Pachinger O, Frick M, Ulmer H. Liver dysfunction in chronic heart failure: prevalence, characteristics and prognostic significance. Eur J Clin Invest 2012; 42:153-163. 